Pesq. Vet. Bras. 37(8):891-896, agosto 2017

DOI: $10.1590 / \mathrm{S} 0100-736 \mathrm{X} 2017000800019$

\title{
Evaluation of neonatal vitality and blood glucose, lactate and cortisol concentrations in foals of the Paint Horse breed ${ }^{1}$
}

\author{
Raíssa K.S. Cruz ${ }^{2}$, Angélica Alfonso ${ }^{2}$, Fabiana F. Souza ${ }^{3}$, Eunice $\mathrm{Oba}^{3}$, Carlos R. Padovani ${ }^{4}$, \\ Paulo R.R. Ramos ${ }^{5}$, Maria Lúcia G. Lourenço ${ }^{2 *}$ and Simone B. Chiacchio ${ }^{2}$
}

\begin{abstract}
Cruz R.K.S., Alfonso A., Souza F.F., Oba E., Padovani C.R., Ramos P.R.R., Lourenço M.L.G. \& Chiacchio S.B. 2017. Evaluation of neonatal vitality and blood glucose, lactate and cortisol concentrations in foals of the Paint Horse breed. Pesquisa Veterinária Brasileira 37(8):891-896. Faculdade de Medicina Veterinária e Zootecnia, Unesp, Campus Botucatu, Distrito Rubião Júnior s/n, Botucatu, SP 18618-970, Brazil. Email: mege@fmvz.unesp.br

Clinical evaluations of newborns, as well as defining the therapeutic decision, represent significant challenges to the veterinarian. This study aimed to evaluate neonatal vitality using the modified Apgar score and blood glucose, lactate, and cortisol concentrations in newborn equines. Twenty foals of the Paint Horse breed born by normal delivery were evaluated during the first 48 hours of life. The modified Apgar score was determined at birth and 10 minutes later, with values ranging from 0 to 10 . Blood samples for the laboratory tests were collected at birth and at $4,8,12,16,20,24,36$, and 48 hours. The mean Apgar score was significantly lower at birth than at 10 minutes $(p<0.001)$. Blood glucose concentrations increased significantly between birth $(98.90 \pm 35.97 \mathrm{mg} / \mathrm{dL})$ and 8 hours $(127.90 \pm 27.15 \mathrm{mg} / \mathrm{dL})$, stabilizing after the first 12 hours $(148.95 \pm 29.59 \mathrm{mg} / \mathrm{dL})$. Serum lactate concentrations showed a significant decrease across the time points tested, with the highest value occurring at birth $(5.48 \pm 2.17 \mathrm{mmol} / \mathrm{L})$ and stabilizing after 24 hours $(2.76 \pm$ $1.31 \mathrm{mmol} / \mathrm{L})$. Cortisol concentrations significantly decreased $(\mathrm{p}<0.01)$ between $4(10.46$ $\pm 7.46 \mu \mathrm{g} / \mathrm{dL})$ and 48 hours $(5.21 \pm 3.35 \mu \mathrm{g} / \mathrm{dL})$, with the highest value occurring 4 hours after birth. The common occurrence of laboratory abnormalities in healthy newborn foals reinforces the need to conduct regular clinical examinations and to develop laboratory reference values for different breeds and ages.
\end{abstract}

INDEX TERMS: Neonate equine, apgar score, lactatemia, glycemia, neonatal stress.

RESUMO.- [Avaliação dos padrões de vitalidade neonatal, glicemia, lactato e cortisol em potros da raça Paint Horse.] A avaliação clínica dos recém-nascidos, bem como a definição da conduta terapêutica adotada representam expressivos desafios ao Médico Veterinário. 0 objetivo deste estudo foi avaliar a vitalidade neonatal pelo escore de

\footnotetext{
${ }^{1}$ Received on March 7, 2016.

Accepted for publication on January 31, 2017.

${ }^{2}$ Departamento de Clínica Veterinária, Faculdade de Medicina Veterinária e Zootecnia, Universidade Estadual Paulista (Unesp), Campus Botucatu, Distrito Rubião Júnior s/n, Botucatu, SP 18618-970, Brazil. *Corresponding author: mege@fmvz.unesp.br

${ }^{3}$ Departamento de Reprodução Animal e Radiologia Veterinária, Faculdade de Medicina Veterinária e Zootecnia, Unesp, Campus Botucatu, Distrito Rubião Júnior s/n, Botucatu, SP 18618-970.

${ }^{4}$ Departamento de Bioestatística, Instituto de Biociência, Unesp, Rua Prof. Dr. Antonio Celso Wagner Zanin s/n, Botucatu, SP 18618-689.

${ }^{5}$ Departamento de Física e Biofísica, Instituto de Biociências, Unesp, Rua Prof. Dr. Antonio Celso Wagner Zanin s/n, Botucatu, SP 18618-689.
}

Apgar modificado, glicemia, lactatemia e cortisol em neonatos equinos. Para tal, foram utilizados 20 potros da raça Paint Horse, nascidos em eutocia, durante as primeiras 48 horas de vida. 0 escore de Apgar modificado foi realizado ao nascimento e 10 minutos após, atribuindo-se notas de 0 a 10. As colheitas das amostras de sangue, para a realização das análises laboratoriais, ocorreram nos momentos ao nascimento, 4, 8, 12, 20 16, 20, 24, 36 e 48 horas de vida. A média do escore de Apgar ao nascimento foi significativamente menor que aos 10 minutos $(\mathrm{p}<0,001)$. A glicemia aumentou significativamente entre o nascimento $(98,90 \pm$ $35,97 \mathrm{mg} / \mathrm{dL})$ e às 8 horas $(127,90 \pm 2327,15 \mathrm{mg} / \mathrm{dL})$, com estabilização após as primeiras 12 horas $(148,95 \pm 29,59$ $\mathrm{mg} / \mathrm{dL}$ ). A concentração sérica de lactato apresentou decréscimo significativo entre os momentos estudados, sendo o maior valor encontrado ao nascimento $(5,48 \pm 2,17$ $\mathrm{mmol} / \mathrm{L})$, com estabilização a partir das 24 horas $(2,76 \pm$ $1.31 \mathrm{mmol} / \mathrm{L}$ ). As concentrações de cortisol, reduziram 
significativamente $(\mathrm{p}<0,01)$, entre as $4(10,46 \pm 7,46 \mu \mathrm{g} /$ $\mathrm{dL})$ e as 48 horas $(5,21 \pm 3,35 \mu \mathrm{g} / \mathrm{dL})$, sendo o maior valor encontrado as 4 horas após o nascimento. A ocorrência comum de anormalidades laboratoriais em potros recém-nascidos, aparentemente saudáveis, reforça a necessidade da realização de exames clínicos regulares e o desenvolvimento de valores laboratoriais de referência, em diferentes raças e idades.

TERMOS DE INDEXAÇÃO: Equino neonato, escore de apgar, lactatemia, glicemia, estresse neonatal.

\section{INTRODUCTION}

Among the barriers in horse breeding, neonatal mortality attributed to cardiovascular, pulmonary, metabolic and thermoregulatory abnormalities stands out (Smith 2006). Equine neonatal sepsis (ENS) and perinatal asphyxia syndrome (PAS) are the major causes of morbidity and mortality in newborn foals (Galvin \& Corley 2010). In Brazil, a study by Frey Jr (2006) in Bage in Rio Grande do Sul found a morbidity rate of $76.6 \%$ and a mortality rate of $2.5 \%$, suggesting that appropriate assistance for newborns is necessary to reduce neonatal mortality.

An understanding of neonatal physiology, the ability to evaluate the vigor of a newborn, and rapid intervention with respect to resuscitation are essential to decrease neonatal mortality. The adoption of simple measures, including the use of neonatal vitality scores, may guide the most adequate therapeutic choice for ensuring and increasing the survival of the newborn (Cruz et al. 2015).

Neonatal vitality can be assessed using the Apgar score, which is based on a visual assessment of the newborn (Montillo et al. 2014). The Apgar score ranges from zero to 10 , with values at birth between nine and 10 considered optimal for the equine species. Grades from six to eight indicate moderate asphyxia, suggesting the adoption of neonatal stimulation measures (Vaala et al. 2006). Foals with scores between three and five require intranasal oxygen and cardiovascular support, and those with scores lower than three require immediate resuscitation.

In mammals, cortisol promotes the adaptation of various physiological conditions, including pregnancy, delivery, onset of lactation, and maturation of fetal systems and organs (Farrand et al. 2006, Ousey 2006, Montillo et al. 2014). Cortisol affects multiple metabolic systems, including the use of glucose and fat and protein catabolism, and stimulates changes in heart rate (HR) and blood pressure (Yamada et al. 2007).

The use of blood lactate concentrations as an indicator of disease prognosis and severity has become a common practice in equine medicine, particularly with the use of portable analyzers. However, few authors have reported lactate concentrations in healthy newborn foals (Castagnetti et al. 2010, Veronesi et al. 2014).

In-depth studies of the physiology of equine neonates and its clinical evolution in the immediate postpartum period may help to improve veterinary neonatology. The evaluation of neonatal vitality using the Apgar score and laboratorial parameters (lactate, cortisol and glucose) are practical and reliable methods in newborn humans and animals. The authors believe that stabilization of the clinical and laboratory status soon after birth occurs gradually and is indicative of suitable organic adaptation to the extra-uterine environment.

\section{MATERIALS AND METHODS}

Mares. The present study was conducted at a horse farm located in Avaré Municipality, State of São Paulo, at 766 meters altitude, $23^{\circ} 05^{\prime} 55^{\prime \prime}$ latitude, $48^{\circ} 55^{\prime} 3^{\prime \prime}$ longitude, with a subtropical climate and temperatures ranging from 16.8 to $21.7^{\circ} \mathrm{C}$. All of the experimental procedures were performed after obtaining approval from the Animal Research Ethics Committee (CEUA/UNESP 231/2012).

Twenty foals of the Paint Horse breed, bred using the embryo transfer (ET) technique in crossbred recipients $(n=20$, mean age: 5 to 12 years, $450 \mathrm{~kg}$ mean weight), were evaluated. Ultrasound examinations were performed prior to delivery to ensure fetal viability. Endoparasites were controlled through worming in accordance with the results of fecal examinations. The mares were vaccinated with Pneumabort- $\mathrm{K}^{\circledR}+1 \mathrm{~b}$ (Equine rhinopneumonitis, Zoetis Animal Health Specials, Canada) at the 5th, 7th, and 9th month of pregnancy and were maintained by grazing on Tifton 85 (Cynodon dactylon). Four kilograms of commercial feed (pelleted Guabi®, Guabi Animal Nutrition, Campinas, SP, Brazil) was offered daily; the feed consisted of $15 \%$ crude protein, $4 \%$ crude fat, $12 \%$ crude fiber, $12 \%$ mineral matter, $1.8 \%$ calcium and $0.5 \%$ phosphorus, and it was divided into two portions given in the morning $(2 \mathrm{~kg}$ ) and in the late afternoon $(2 \mathrm{~kg})$. The mares had ad libitum access to fresh water and mineral salt (Coequi Plus, Tortuga $^{\circledR}$, São Paulo, Brazil).

The inclusion criteria considered for the study were foals born through natural birth: delivery in lateral recumbency, expulsion within 20 minutes, assisted delivery without requiring obstetric intervention (rupture of fetal membranes or forced extraction), dorsal-anterior presentation of the fetus, and spontaneous rupture of the umbilical cord. The mean duration of pregnancy and delivery were also assessed.

Foals. Newborns remained with their mothers throughout the experimental period. The foals were evaluated immediately after birth with respect to their attitude and behavior (alertness, maternal interaction, assessment of overall shape, teat-seeking activity, and sucking reflex) and vital signs (color and appearance of the mucous membranes; capillary refill time; pulse; body temperature; heart, lung, and abdominal auscultation [HR, respiratory rate (RR), and respiratory pattern]); inspection of the abdominal and umbilical region to check for hernias and abdominal distension; observation of urination; and passage of meconium.

Foal maturity was assessed according to the absence of the following clinical signs of immaturity proposed by Madigan (2013): weakness and depression (inability to stand or exhibit the sucking reflex); size at birth; appearance of the hooves and fur; bulging forehead, hyperemic mucous membranes, droopy ears, and lips; hypothermia; hyperextension or hypoflexion of the fetlock joints (angle deformities); and respiratory distress.

The behavior of the foal after birth was also assessed. Healthy foals with the following characteristics were included in the study: sternal recumbency (from 5 to 10 minutes), sucking reflex (5-20 minutes), time to stand (mean of 60 minutes), first sucking (up to 2 hours), and passage of meconium (3-12 hours) (Koterba et al. 1990, Kurtz Filho et al. 1997, Pierce 2003, Paradis 2006, Vaala et al. 2006, Curcio \& Nogueira 2012). The foals were monitored during the 48 hours of study with respect to the clinical parameters heart rate $(\mathrm{HR}-\mathrm{bpm})$, respiratory rate $(\mathrm{RR}-\mathrm{mpm})$, 
and temperature $\left({ }^{\circ} \mathrm{C}\right)$, which were evaluated at the aforementioned nine time points. The reference limits considered for the body temperature of neonatal foals were $37.5^{\circ} \mathrm{C}$ at birth and $38.0^{\circ} \mathrm{C}$ at 24 hours (Knottenbelt et al. 2004). The following values were considered for HR: $>60 \mathrm{bpm}$ from 1 to 5 minutes after birth, 80$130 \mathrm{bpm}$ from 6 to 60 minutes, and $80-120 \mathrm{bpm}$ from 1 day to 5 days (Madigan 2013); the following values were considered for $\mathrm{RR}, 60-\mathrm{mpm}$ in the first 30 minutes after birth, 30-40 mpm from 1 to 12 hours (Madigan 2013), and 30mpm at 24 hours (Knottenbelt et al. 2004).

Blood samples $(5 \mathrm{~mL})$ were collected by jugular venipuncture using $25 \times 8 \mathrm{~mm}$ needles and disposable plastic syringes. Samples were taken at birth and at $4,8,12,16,20,24,36$, and 48 hours of age.

Apgar score. The Apgar score, modified by Knottenbelt et al. (2004), Smith (2006), and Nogueira \& Lins (2010), consisting of evaluating HR, RR, muscle tone, reflex irritability, and color of the mucous membranes, was used to evaluate neonatal vitality (Table 1). Grades from 0 to10 ( 0 =dead; $1-4=$ depressed; 4-6 =moderately depressed and 7-10 =vigorous) were assigned at the time of birth and 10 minutes later.

Table 1. Apgar score modified from Knottenbelt et al. (2004), Smith (2006), and Nogueira \& Lins (2010)

\begin{tabular}{lccc}
\hline Parameters & 0 points & 1 point & 2 points \\
\hline Muscle tone & Limp extremities & Some flexion of limbs & Sternal \\
Respiration & Absent & Slow, Irregular & $\geq 60 \mathrm{mpm}$, Regular \\
Heart rate & Absent & $<60 \mathrm{bpm}$ & $\geq 60 \mathrm{bpm}$ \\
Nasal stimulation & No response & Grimace, slight rejection & Cough or sneeze \\
Mucous membranes & Cyanotic & Pale pink & Pink
\end{tabular}

Laboratory tests. Blood glucose and lactate concentrations were assessed using portable analyzers and a drop of total blood for each test (Accu-Chek ${ }^{\circledR}$ Advantage, Roche Diagnostics, Brazil, and Accutrend ${ }^{\circledR}$ Plus, Roche, Mannheim, Germany, for blood glucose and lactate concentrations, respectively) (Tennent-Brown et al. 2007, Hollis et al. 2008). In this study, the following laboratory values were adopted: blood glucose $(96-176 \mathrm{mg} / \mathrm{dL}$ ) (Paradis 2006), and lactate (first 24 hours: $3 \pm 0.04$ to $4.9 \pm 1.02 \mathrm{mmol} / \mathrm{L}$ ) (Axon \& Palmer 2008).

The blood samples used to assess cortisol concentrations were stored in glass tubes without anticoagulant and kept at room temperature to facilitate clot retraction. The samples were then centrifuged for 5 minutes at $3000 \mathrm{rpm}$ to collect sera, which were stored in 2-mL microcentrifuge tubes in a freezer at $-20 \underline{o} \mathrm{C}$. Cortisol measurements were conducted with a commercial radioimmunoassay test (Coat-a-count ${ }^{\circledR}$, Diagnostic Products Corporation, Los Angeles, CA, USA) according to the manufacturer's recommendations. For the intra-assay coefficient, 360 tubes were analyzed from 20 foals during the nine sampling moments, and the analyzes were done in duplicate. To evaluate the inter-assay, a mean from the 20 foals was obtained in the same moments. The coefficients of inter- and intra-assay variation for the cortisol measurements were $0.62 \%(48.70 \mathrm{~g} / \mathrm{dL})$ for the upper control and $1.08 \%(1.07 \mathrm{~g} / \mathrm{dL})$ for the lower control.

Statistical analysis. For the statistical analysis of the Apgar score, a normality test (Kolmogorov-Smirnov) was performed followed by an independent $t$ test. For the remaining variables (HR, RR, temperature, blood glucose, lactate and cortisol concentration), a normality test (Kolmogorov-Smirnov) was performed followed by analysis of variance (ANOVA) for repeated measures. Tukey's test was used to analyze the p-values resulting from multiple comparisons. In addition, Pearson's correlation was calculated (PROC CORR in SPSS) between dependent variables among each time point assessed. The data are reported as untransformed least-squares means \pm standard deviations. For all analyses, $\mathrm{p}<0.05$ was considered significant (PROC MIXED, SAS Institute 2011).

\section{RESULTS}

The mean duration of pregnancy was $332.25 \pm 17.47$ days, the deliveries lasted from 20 to 30 minutes from rupture of fetal membranes to complete delivery of the foal, and no foals showed signs of dysmaturity. A total of 75\% (15) of the deliveries occurred in the evening period, $40 \%$ (08) of the foals were born between 3:00 and 5:00 am, 35\% (07) between $6: 30$ and 11:00 pm, 15\% (03) of the deliveries occurred in the afternoon (12:30-5:00pm), and 10\% (02) of the deliveries occurred in the morning (7:00-8:00am).

Regarding the behavior at birth (Apgar score at birth), $80 \%$ (16) of the foals showed some flexion of limbs (muscle tone) and $20 \%$ (04) of the foals were born, and already stayed in sternal recumbency; $90 \%$ (18) of the foals displayed reflex irritability, and this reflex was absent in $10 \%$ (02) of the foals; the mucous membrane color was pinkish in $60 \%$ (12) of the foals, congested in $20 \%$ (04) of the foals, and pale in $20 \%$ (04) of the foals.

A total of 35\% (07) of the foals flexed their limbs, and 65\% (13) showed sternal recumbency 10 minutes after birth (Apgar for 10 minutes); the mean time for reaching sternal recumbency was five minutes. A total of $90 \%$ (18) of the foals showed reflex irritability, and this reflex was still absent in 10\% (02). Mucous membrane color did not change from birth to 10 minutes after birth.

The foals attempted to stand after 10 minutes of life, without exceeding 30 minutes; they exhibited teat-seeking activity, and the sucking reflex (sucking reflex present) from 40 minutes to 1 hour, and passage of meconium was initiated from 1 hour 30 minutes to 10 hours after birth; and the first sucking occurred from 45 minutes to 2 hours.

The Apgar scores are expressed as the mean \pm standard deviation. A significant difference was observed between the two time points analyzed $(\mathrm{p}<0.001)$, with means of $7.80 \pm 0.89$ at birth and $8.35 \pm 0.99$ at 10 minutes after birth. No significant correlations were found between the modified Apgar scores and other study variables among the time points assessed.

The clinical parameters HR and breathing showed statistically significant differences, although they varied between the times analyzed. Body temperature exhibited significant increases $(\mathrm{p}<0.001)$ between birth $\left(37.96 \pm 0.84^{\circ} \mathrm{C}\right)$ and 20 hours after birth $\left(38.50 \pm 0.40^{\circ} \mathrm{C}\right)$, as well as 36 hours after birth $\left(38.64 \pm 0.42^{\circ} \mathrm{C}\right)$ (Table 2 ).

There was no significant difference between the blood glucose concentrations at birth $(98.90 \pm 35.97 \mathrm{mg} / \mathrm{dL})$ and 4 hours after birth $(108.05 \pm 26.23 \mathrm{mg} / \mathrm{dL})$, although a significant increase occurred between birth and 8 hours after birth $(127.90 \pm 27.15 \mathrm{mg} / \mathrm{dL})$. The blood glucose concentrations stabilized at $148.95 \pm 29.59 \mathrm{mg} / \mathrm{dL}$ after the first 12 hours (Table 3).

Blood lactate concentrations decreased across the time points tested, with the highest value measured at birth $(5.48 \pm 2.17 \mathrm{mmol} / \mathrm{L})$. Significant differences were detected 
Table 2. Mean and standard deviation of clinical parameters in 20 foals at birth and 4, 8, 12, 16, 20, 24, 36 and 48 hours postpartum

\begin{tabular}{lccc}
\hline Time & Temperature $\left({ }^{\circ} \mathrm{C}\right)$ & Heart rate $(\mathrm{bpm})$ & Respiratory rate $(\mathrm{mpm})$ \\
\hline Birth & $37.97 \pm 0.85 \mathrm{a}$ & $137.20 \pm 30.49$ & $55.20 \pm 27.73$ \\
$4 \mathrm{~h}$ & $38.05 \pm 0.47 \mathrm{ab}$ & $128.60 \pm 39.11$ & $44.20 \pm 15.65$ \\
$8 \mathrm{~h}$ & $38.22 \pm 0.53 \mathrm{abc}$ & $119.90 \pm 34.71$ & $49.60 \pm 34.78$ \\
$12 \mathrm{~h}$ & $38.23 \pm 0.41 \mathrm{abc}$ & $124.00 \pm 30.49$ & $45.80 \pm 15.81$ \\
$16 \mathrm{~h}$ & $38.38 \pm 0.28 \mathrm{bcd}$ & $123.80 \pm 26.61$ & $50.40 \pm 20.62$ \\
$20 \mathrm{~h}$ & $38.46 \pm 0.34 \mathrm{~cd}$ & $122.00 \pm 22.35$ & $48.40 \pm 27.86$ \\
$24 \mathrm{~h}$ & $38.48 \pm 0.36 \mathrm{~cd}$ & $123.00 \pm 26.75$ & $52.00 \pm 25.27$ \\
$36 \mathrm{~h}$ & $38.64 \pm 0.43 \mathrm{~d}$ & $113.60 \pm 17.29$ & $49.00 \pm 19.11$ \\
$48 \mathrm{~h}$ & $38.44 \pm 0.55 \mathrm{bcd}$ & $120.40 \pm 31.23$ & $42.60 \pm 16.01$ \\
$\mathrm{p}$ value & $<0.001$ & $>0.05$ & $>0.05$
\end{tabular}

a.b Different superscripted letters indicate significant differences between time points $(\mathrm{p}<0.05)$.

Table 3. Mean and standard deviation of biochemical analyses and cortisol levels in 20 foals at birth and 4, 8, 12, 16, 20, 24, 36 and 48 hours postpartum

\begin{tabular}{lccc}
\hline Time & Lactate $(\mathrm{mmol} / \mathrm{L})$ & Cortisol $(\mu \mathrm{g} / \mathrm{dL})$ & Glucose $(\mathrm{mg} / \mathrm{dL})$ \\
\hline Birth & $5.48 \pm 2.17 \mathrm{~d}$ & $9.89 \pm 7.25 \mathrm{~cd}$ & $98.90 \pm 35.97 \mathrm{a}$ \\
$4 \mathrm{~h}$ & $4.58 \pm 1.67 \mathrm{~cd}$ & $10.46 \pm 7.46 \mathrm{~d}$ & $108.05 \pm 6.23 \mathrm{ab}$ \\
$8 \mathrm{~h}$ & $4.26 \pm 1.63 \mathrm{bcd}$ & $6.90 \pm 5.25 \mathrm{abc}$ & $127.90 \pm 27.15 \mathrm{bc}$ \\
$12 \mathrm{~h}$ & $3.82 \pm 1.79 \mathrm{abc}$ & $6.13 \pm 4.57 \mathrm{bcd}$ & $148.95 \pm 29.59 \mathrm{~cd}$ \\
$16 \mathrm{~h}$ & $3.42 \pm 1.78 \mathrm{abc}$ & $5.52 \pm 4.58 \mathrm{abc}$ & $154.10 \pm 29.19 \mathrm{~d}$ \\
$20 \mathrm{~h}$ & $3.07 \pm 1.73 \mathrm{abc}$ & $4.45 \pm 5.01 \mathrm{ab}$ & $160.05 \pm 20.68 \mathrm{~d}$ \\
$24 \mathrm{~h}$ & $2.76 \pm 1.31 \mathrm{ab}$ & $4.97 \pm 4.70 \mathrm{a}$ & $166.55 \pm 18.96 \mathrm{~d}$ \\
$36 \mathrm{~h}$ & $2.51 \pm 0.96 \mathrm{a}$ & $5.47 \pm 4.73 \mathrm{ab}$ & $161.00 \pm 17.17 \mathrm{~d}$ \\
$48 \mathrm{~h}$ & $2.43 \pm 0.87 \mathrm{a}$ & $5.21 \pm 3.35 \mathrm{abc}$ & $155.70 \pm 19.37 \mathrm{~d}$ \\
$\mathrm{p}$ value & $<0.001$ & $<0.01$ & $<0.001$
\end{tabular}

$\overline{\text { a.b }}$ Different superscripted letters indicate significant differences between time points $(\mathrm{p}<0.05)$.

between birth and $24(2.76 \pm 1.31 \mathrm{mmol} / \mathrm{L})$ and 36 hours $(2.51 \pm 0.96 \mathrm{mmol} / \mathrm{L})$ after birth but stabilized after 24 hours $(\mathrm{p}<0.001)$ (Table 3).

Cortisol concentrations were highest at birth $(9.89 \pm 7.25 \mu \mathrm{g} / \mathrm{dL})$ and 4 hours after birth $(10.46 \pm 7.46 \mu \mathrm{g} /$ $\mathrm{dL}$ ). The concentrations then significantly decreased from birth to $20(4.45 \pm 5.01 \mu \mathrm{g} / \mathrm{dL}), 24(4.97 \pm 4.70 \mu \mathrm{g} / \mathrm{dL})$, and 36 hours $(5.47 \pm 4.73 \mu \mathrm{g} / \mathrm{dL})$. There were also significant decreases between 4 hours and $8(6.90 \pm 5.25 \mu \mathrm{g} / \mathrm{dL}), 16$ $(5.52 \pm 4.58 \mu \mathrm{g} / \mathrm{dL}), 20,24,36$, and 48 hours $(5.21 \pm 3.35 \mu \mathrm{g} /$ dL) (Table 3).

Positive correlations between cortisol and lactate concentrations were present at 12 and 16 hours postpartum ( $[\mathrm{r}=0.67, \mathrm{p}=0.001]$ and $[\mathrm{r}=0.58, \mathrm{p}=0.006]$, respectively). The cortisol and lactate concentrations were negatively correlated at 4 hours ( $r=-0.47, p=0.03)$, and body temperature and cortisol were negatively correlated between 4 and 48 hours after birth $([\mathrm{r}=-0.46, \mathrm{p}=0.03]$ and $[\mathrm{r}=-0.71$, $\mathrm{p}=0.0001]$, respectively).

\section{DISCUSSION}

The mean of Apgar score remained between seven and eight at the first two time points assessed, and the animals were healthy until 48 hours of life. These results differed from values reported in foals also born from natural delivery (Panzani et al. 2009) but were similar to those reported for newborn foals at the same periods of evaluation (Comin et al. 2012). The variation observed between the analyzed time points corresponds to the period of adaptation to extra-uterine life, where spontaneous breathing and adjustment of the cardiocirculatory and respiratory systems, among other functions previously performed by the placenta, are established. The mean modified Apgar scores are considered normal for newborn foals (Lu et al. 2006, Paradis 2006). However, other authors have noted that scores between six and eight suggest the presence of moderate asphyxia, with indications for the adoption of neonatal resuscitation measures (Vaala et al. 2006). Nonetheless, the animals in this study did not display clinical alterations matching any degree of asphyxia, and interventions were not necessary.

Body temperature was lower at birth, likely because of immaturity of the temperature regulating centers, the large exposed body surface, and a lack of subcutaneous tissue, which are factors that favor increased heat loss in these newborns. Heat loss may also result from the lack of a thermal insulation layer (fat brown) in newborns (Calil 1996). The thermoregulatory system is not developed at birth, so heat is a critical factor for neonatal survival. As in the adult, the newborn is poikilotherm, and your body temperature is directly related to the environment, so the neonate is unable to control the temperature in the first four weeks of age (Poffenbarger 1990, Peterson \& Kutzler 2011). Another relevant factor is that foals are born wrapped in amniotic fluid, and its evaporation produces a significant loss of heat by convection. The body temperature remained significantly high at the other assessed time points, given the colostrum intake, increased metabolism, and movement of the foal. However, the temperature reached was considered physiological for newborn foals up to four days of age (Koterba et al. 1990). A negative correlation was observed between body temperature and cortisol concentrations, and the results suggest that changes in secretion patterns and levels of hormones, as well as changes in rectal temperature, it can be influenced by many factors, such the environmental changes, seasonal breeding, and required metabolic energy in the neonate foals. These results suggest that the foals make an effort to conserve the body temperature in low environment temperatures, and their physiological functions adapt to seasonal changes in their external environments (Funasaka et al. 2011).

The animals of this study were normoglycemic according to the standards proposed by Paradis (2006), Fenger (2000), Knottenbelt et al. (2004), and Bromerschenkel et al. (2015). The maintenance of glucose homeostasis immediately after delivery is dependent on liver glycogen stores, which should be sufficient to provide energy before breastfeeding. When the maternal nutrition is adequate, the neonatal glucose availability is sufficient for the initial needs (Landim-Alvarenga 2006). Lower values were described by Pirrone et al. $(2012,2014)$ in total blood of different breeds of foals at birth, using the same methodology of this study, but differents brands. And this differences can be related with the type of brand used, since that the portable clinical analyzer was adopted in this study.However, the analyzer used in this study, was validated and demonstrated similar accuracy to laboratory test in determining glucose levels in neonatal foals (Bromerschenkel et al. 2015). Glucose concentrations significantly increased across the time points evaluated, potentially because of colostrum intake. 
The lactate values at birth were superior to those described by Castagnetti et al. (2010) for healthy foals, and the authors validated for the first time, the portable analyzer to assess blood lactate concentration in critically ill and healthy foals. But according to the authors, the analyzer seems to underestimate lactate values $>5 \mathrm{mmol} / \mathrm{L}$, and the veterinary should therefore interpret higher lactate concentrations critically and possibly monitor lactate concentration more frequently. However, all animals of this study were monitored for at least 6 months and found themselves healthy. Pirrone et al. (2012) reported that at birth, sick foals did not have higher blood lactate concentration than healthy foals, although sick foals cleared lactate more slowly than the healthy. ccording the authors, the lower arterial lactate concentration obtained of the equine fetus $(1.0 \pm 0.20 \mathrm{mmol} / \mathrm{L})$ from middle to late gestation, supported the hypothesis that higher concentrations measured at birth occured due the release of cortisol and catecholamine, or due to physiological hypoxia during the birth process.

Blood lactate concentrations significantly decreased between birth, and 24 hours after birth, such decreases are similar to patterns reported by other authors (Axon \& Palmer 2008), and are associated with the gradual clearance, and consumption of lactate through pyruvate conversion for energy production, thus reversing tissue hypoxia, and favoring the neonatal prognosis (Souza \& Elias 2006). Positive correlations between lactate and cortisol have also been reported by other authors and may be related to the release of catecholamines during the delivery process or even with physiological hypoxia at birth (Rossdale et al. 1984, Fowden et al. 2000). Animal age should thus be considered when analyzing these concentrations, especially during the first 24 hours because these increases can be related to the period of neonatal adaptation, and are not necessarily indicative of morbidity.

The stimulation of the hypothalamic-pituitary-adrenal (HPA) axis and increased cortisol concentrations in fetal plasma are associated with neonatal maturity, viability, and adaptation to independent life in horses (Panzani et al. 2009). In order to evaluate the longer-duration of dynamic changes in cortisol secretion attributed to stress responses and to avoid stress caused by repeated blood collections some authors establish the determination of cortisol through salivary analysis (Nagel et al. 2015), assessment of fur cortisol concentrations in foals (Montillo et al. 2014), calculation of average daily cortisol concentrations via an indwelling catheter (Malarkey et al. 1995), or measurement of fecal cortisol metabolites (Schmidt et al. 2010). However, this methods are to measure the chronic stress due to the potential for ACTH/cortisol dissociation and down-regulation of the HPA axis with many instances of chronic, long-term stress (Bornstein et al. 2008), which is not the purpose of the present study, thus, plasmatic evaluation was adopted (Hart 2012).

The cortisol concentrations found in the present study were higher than the values reported for the plasma of full-term foals at birth and 30 minutes (Silver et al. 1991, Panzani et al. 2009), and in another study realized in foals fur, at birth (Comin et al. 2012). It is well known that, during the first few hours after parturition, newborns have high cortisol levels in response to the stress of labor, birth, and adaptation to extrauterine life (Elverson \& Wilson 2005). Other factor that may lead to increased blood cortisol levels during the measurement is the stress of animal restraint, which leads to increased circulating adrenaline and then increased blood cortisol. To minimizing stress, all samples from foals were colleted with their mares, in a quiet place, and the restraint was performed by qualified persons, in order to generate the least possible changes. However, even taking these precautions, some animals may have shown changes in response to stress.

The decrease in cortisol concentrations observed in this study occurred because of fast metabolism between the beginning of labor and birth, which increased glucose serum concentrations through gluconeogenesis and thus maintained the body temperature of neonates within physiological limits. Nagel et al. (2012) also found maximum concentrations of cortisol when the foals were standing and after the ingestion of colostrum. In calves, the opposite effect on plasma cortisol levels is observed, and the release of catecholamines during delivery can increase and then decrease after birth (Aurich et al. 1993). Cortisol concentrations were the highest in the first 4 hours of life (Rossdale et al. 1984), which corresponds to the period of adaptation to extrauterine life and the stress caused by labor (Panzani et al. 2009, Elverson \& Wilson 2005); therefore, cortisol analysis should not be considered the only method to evaluate the health of the newborn. Other health evaluations are recommended.

\section{CONCLUSIONS}

The modified Apgar score proved to be an effective marker of short-term neonatal vitality in equines, as the foals remained viable until 48 hours of life, with satisfactory scores of seven to eight.

Glucose concentrations were lower at birth, increasing over time and stabilizing at 12 hours of life.

All foals in this study were normoglycemic; therefore, the use of glucose was not required as a resuscitation measure.

Blood lactate concentrations should not be used as the only method of evaluating neonatal vitality but rather should be considered in association with other variables and a clinical examination of the animal.

In foals, high concentrations of lactate and cortisol at birth should be cautiously interpreted because they may simply reflect a physiological pattern during the fetal-neonatal transition.

Acknowledgements.- The authors thank the São Paulo Research Foundation (Fundação de Amparo à Pesquisa do Estado de São Paulo, FAPESP) for financial support. The authors also ackoweledge the Escaramuça farm for allowed the use of animals in the present study.

\section{REFERENCES}

Aurich J.E., Dobrinski I., Petersen A., Grunert E., Rausch W.D. \& Chan W.W. 1993. Influence of labor and neonatal hypoxia on sympathy o adrenal 
activation and methionine enkephalin release in calves. Am. J. Vet. Res. 54:1333-1338.

Axon J.E. \& Palmer J.E. 2008. Clinical pathology of the foal. Vet. Clin. North Am., Equine Pract. 24:357-85.

Bornstein S., Engeland W., Erhart-Bornstein M. \& Herman J. 2008. Dissociation of ACTH and glucocorticoids. Trends Endocrinol. Metabol. 19:175180.

Bromerschenkel I., Porfírio L.C. \& Martins C.B. 2015. Use of portable glucometer of glycemia measurement in Mangalarga Marchador neonatal foals. Acta Vet. Brasilica 9:369-374.

Calil V.M.L.T. 1996. Caracterização do recém-nascido pré-termo, p.79-95. In: Leone C.R. \& Tronchin D.M.R. (Eds), Assistência Intergrada ao Recém-Nascido. Atheneu, São Paulo.

Castagnetti C., Pirrone A., Mariella J. \& Mari G. 2010. Venous blood lactate evaluation in equine neonatal intensive care. Theriogenology 73:343357.

Comin A., Veronesi M.C., Montillo M., Faustini M., Valentini S., Cairoli F. \& Prandi A. 2012. Hair cortisol level as a retrospective marker of hypothalamic-pituitary-adrenal axis activity in horse foals. Vet. J. 194:131-132.

Cruz R.K.S., Alfonso A., Lourenço M.L.G., Ulian C.M.V., Sudano M.J., Oba E., Padovani C.R., Ramos P.R.R. \& Chiacchio S.B. 2015. Electrolyte, Blood gas and electrocardiographic profile of neonatal foals in the first 48 hours of life. Acta Scient. Vet. 43:1321.

Curcio B.R. \& Nogueira C.E.W. 2012. Newborn adaptation and healthcare throughout the first age of the foal. Anim. Reprod. Sci. 9:182-187.

Elverson C.A. \& Wilson M.E. 2005. Cortisol: circadian rhythm and response to a stressor. Newborn Infant. Nurs. Rev. 5:159-169.

Farrand K., McMillen I.C., Tanaka S. \& Schwartz J. 2006. Subpopulations of corticotrophs in the sheep pituitary during late gestation: effects of development and placental restriction. Endocrinology 147:4762-4771.

Fenger C.K. 2000. Doenças de potros, p.803-830. In: Ibid. (Ed.), Medicina Interna Equina. Guanabara Koogan, Rio de Janeiro.

Fowden A.L., Taylor P.M., White K.L. \& Forhead A.J. 2000. Ontogenic and nutritionally induced changes in fetal metabolism in the horse. J. Physiol. 528:209-219.

Frey Jr F. 2006. [Epidemiological indices in thoroughbred foals, from birth to six months of life, in the region Bagé/RS.] Índices epidemiológicos em potros Puro Sangue de Inglês, do nascimento ao sexto mês de vida, na região de Bagé/RS. Master Dissertation, Federal University of Pelotas, RS, Brazil.

Funasaka N., Yoshioka M., Suzuki M., Ueda K., Miyahara H. \& Uchida S. 2011. Seasonal difference of diurnal variations in serum melatonin, cortisol, testosterone, and rectal temperature in indo-pacific bottlenose dolphins (Tursiops aduncus). Aquatic Mammals 37:433-442.

Galvin N.P. \& Corley K.T.T. 2010. Causes of disease and death from birth to 12 months of age in the thoroughbred horse in Ireland. Irish Vet. J. 63:37-43.

Hart K.A. 2012. The use of cortisol for the objective assessment of stress in animals: Pros and Contras. Vet J. 192:137-139.

Hollis A.R., Dallap Schaer B.L., Boston R.C. \& Wilkins P.A. 2008. Comparison of the Accu-Chek Aviva point-of-care glucometer with blood gas and laboratory methods of analysis of glucose measurement in equine emergency patients. J. Vet. Intern. Med. 22:1189-1195.

Knottenbelt D.C., Holdstock N. \& Madigan J.E. 2004. Equine Neonatology: medicine and surgery. Elsevier, Philadelphia.

Koterba A.M., Drummond W.H. \& Kosch P.C. 1990. Equine Clinical Neonatology. Lea and Febiger, Philadelphia.

Kurtz Filho M., Deprá N.M., Alda J.L., Castro I.N., Corte F.D. \& Silva C.A.M. 1997. Physiological and ethological parameters in the thoroughbred newborn foal. Braz. J. Vet. Res. Anim. Sci. 34:103-108.

Landim-Alvarenga F.C., Prestes N.C. \& Fernandes C.B. 2006. Interrupção da gestação e indução de parto. In: Ibid. (Eds), Obstetrícia veterinária. Guanabara Koogan, Rio de Janeiro. 272p.

Lu K.G., Barr B.S., Embertson R. \& Schaer B.D. 2006. Dystocia, a true equine emergency. Clin. Tech. Equine Pract. 5:145-153.
Madigan J.E. 2013. Manual of Equine Neonatal Medicine. 4th ed. Live Oak Publishing, Woodland, CA.

Malarkey W., Pearl D., Demers L., Kiecolt-Glaser J. \& Glaser R. 1995. Influence of academic stress and season on 24-hour mean concentrations of ACTH, cortisol and B-endorphin. Psychoneuroendocrinology 20:499-508.

Montillo M., Comin A., Corazzin M., Peric T., Faustini M., Veronesi M.C., Valentini S., Bustaffa M. \& Prandi A. 2014. The effect of temperature, rainfall, and light conditions on hair cortisol concentrations in newborn foals. J. Equine Vet. Sci. 34:774-778.

Nagel C., Erber R., Bergmaier C., Wulf M., Aurich J., Möstl E. \& Aurich C. 2012. Cortisol and progestin release, heart rate and heart rate variability in the pregnant and postpartum mare, fetus and newborn foal. Theriogenology 78:759-767.

Nagel C., Erber R., Ille N., Wulf M., Aurich J., Möstl E. \& Aurich C. 2015. Heart rate and salivary cortisol concentrations in foals at birth. Vet. J. 203:250-252.

Nogueira C.E.W. \& Lins L.A. 2010. Equine Neonatology and Pediatrics. Editora e Gráfica Universitária da UFPel, Rio Grande do Sul, Brazil.

Ousey J.C. 2006. Hormone profiles and treatments in the late pregnant mare. Vet. Clin. North Am., Equine Pract. 22:727-747.

Panzani S., Villani M., Govoni N., Kindahl H., Faustini M., Romano G. \& Veronesi M.C. 2009. 15-Ketodihydro-PGF2alpha and cortisol plasma concentrations in newborn foals after spontaneous or oxytocin-induced parturition. Theriogenology 71:768-774.

Paradis M.R. 2006. Equine Neonatal Medicine: a case based approach. Elsevier, Philadelphia. 286p.

Peterson M.E. \& Kutzler M.A. 2011. Small Animal Pediatrics. Elsevier Saunders, St Louis.

Pierce S.W. 2003. Foal care from birth to 30 days: practitioner`s perpective. Proc. 49th Annual Convention of the AAEP, p.13-21.

Pirrone A., Mariella J., Gentilini F. \& Castagnetti C. 2012. Amniotic fluid and blood lactate concentrations in mares and foals in the early postpartum period. Theriogenology 78:1182-9.

Pirrone A., Antonelli C., Mariella J. \& Castagnetti C. 2014. Gross placental morphology and foal serum biochemistry as predictors of foal health. Theriogenology 81:1293-1299.

Poffenbarger E.M. 1990. Canine neonatology. I. Physiologics differences between puppies and adults. Compend. Contin. Educ. Vet. 12:16011609.

Rossdale P.D., Ousey J.C., Silver M. \& Fowden A. 1984. Studies on equine prematurity 6: Guidelines for assessment of foal maturity. Equine Vet. J. 16:300-302.

Schmidt A., Biau S., Mostl E., Becker-Birck M., Miorillon B., Aurich J., Faure J.M. \& Aurich C. 2010. Changes in cortisol release and heart rate variability in sport horses during long-distance road transport. Domest. Anim. Endocrinol. 38:179-189.

Silver M., Fowden A.L., Knox J., Ousey J., Cash R. \& Rossdale P.D. 1991. Relationship between circulating tri-iodothyronine and cortisol in the perinatal period in the foal. J. Reprod. Fertil. 44(Suppl.):619-626.

Smith B.P. 2006. Large Animal Internal Medicine. 3rd ed. Manole, São Paulo.

Souza M.H.L. \& Elias D.O. 2006 Prognostic value of lactic acidosis during perfusion. Revta Latinoam. Tec. Extracorp. 13:14-17.

Tennent-Brown B.S., Wilkins P.A., Lindborg S., Russell G. \& Boston R.C. 2007. Assessment of a point of care lactate monitor in emergency admissions of adult horses to a referral hospital. J. Vet. Intern. Med. 21:1090-1098.

Vaala W.E., House J.K. \& Madigan J.E. 2006. Conduta inicial e exame físico do neonato [initial care and physical examination of the newborn]. In: Smith B.P. (Ed.), Large Animal Internal Medicine. 3rd ed. Manole, São Paulo.

Veronesi M.C., Gloria A., Panzani S., Sfirro M.P., Carluccio A. \& Contri A. 2014. Blood analysis in newborn donkeys: hematology, biochemistry, and blood gases analysis. Theriogenology 82:294-303.

Yamada J., Stevens B., De Silva N., Gibbins S., Beyene J., Taddio A., Newman C. \& Koren G. 2007. Hair cortisol as a potential biologic marker of chronic stress in hospitalized neonates. Neonatology 92:42-49. 